\title{
Hanna DERER
}

Parcurile clasate -

monumente istorice ca oricare altele

Deși contribuie decisiv la un climat sănătos și plăcut, de ani de zile, cel puțin arborii din București intră în atenția propriilor beneficiari aproape numai atunci când se produc două feluri de împrejurări. Unul dintre acestea constă în incidentele cele mai mediatizate și anume accidentele care, din nefericire, se soldează uneori nu doar cu pagube materiale. Aproape la fel de prezente în mass media sunt si deja celebrele campanii de „toaletare” care, după cum afirmă specialiștii în domeniu(I căruia îi revine și întreținerea corectă a vegetației), nu se rezumă numai la efecte adverse din punct de vedere estetic, ci pot provoca, pe termen mediu și lung, chiar moartea prematură a copacilor mutilați în acest fel. Evident, aceste genuri de „aparitii” ale arborilor bucuresteni în emisiunile de știri urmărite de publicul larg au darul de a declanșa reacțiile a numeroși actori, fără însă ca unii sau alții sau toți împreună să fi reușit până în prezent să facă schimbările profunde care se impun deja de extrem de mult timp.

Un exemplu recent în acest sens îl constituie intențiile Primăriei Municipiului București de a transforma Parcul Carol într-un pol cultural al Capitalei, intenții declarate public în anul 20I8(I), și care, deocamdată, s-au soldat cu aprobarea propunerii de modificare a limitei aferente zonei construite protejate în cauză, propunere avizată favorabil de către secțiunea „Urbanism și zone construite protejate" a Comisiei Naționale a Monumentelor Istorice (2). Evident, constituirea unui nucleu apt să atragă locuitorii din vecinătate și nu numai este o operațiune de durată dar, cu certitudine, aceasta nu presupune neapărat schimbarea planului urbanistic zonal dedicat zonelor construite protejate din București (3) și nu presupune nici amânarea intervențiilor necesare pentru mentinerea calităților cărora li se datorează potențialul care se dorește a fi valorificat la un moment dat. Or, din acest ultim punct de vedere situația nu pare să se fi schimbat, nici pentru parcuri, precum cel ce poartă numele regelui Carol I, și nici pentru alte tipuri de spații verzi amenajate pe domeniul public, precum plantatiiile de aliniament.

Cel mai elocvent exemplu în acest sens este faptul că pare să fie ignorat în continuare un principiu elementar nu doar pentru prezervarea monumentelor istorice, precum Parcul Carol (dar nu numai) (4) - si anume principiul întreținerii curente, banală, dar atât de necesară ori de câte ori prevenția este de preferat tratării unei afecțiuni deja în curs de desfăsurare. În conformitate cu afirmatiile specialiștilor invocați anterior, întreținerea curentă (reală, și nu așa numita „toaletare”) a vegetatiei se face pe baza unor planuri anuale (5) sau (de ce nu?) multianuale care, de exemplu, prevăd din timp, înlocuiri de exemplare bătrâne sau bolnave. Evident, în cazul spațiilor verzi din cadrul monumentelor istorice - cum este, de exemplu, Parcul Carol - sau din cadrul zonelor construite protejate, aceste programe trebuie avizate favorabil și de către directia de profil cu atributii privind resursa culturală. $\mathrm{Cu}$ privire la acest mod, corect deci, de a întelege întretinerea curentă a spaților verzi amenajate, Primăria Municipiului București și Ministerul Culturii (și Identității Naționale) au purtat în vara anului 2016 o serie de discuții (6). Cu acea ocazie s-a convenit asupra faptului că astfel de planuri necesită timp de elaborare și de avizare (7), 
motiv pentru care ele urmau să devină instrument de lucru curent abia de la începutul anului următor, 2017. Cu toate acestea, până în primăvara anului 2018 , nici un astfel de document nu parcursese circuitul de avizare și, chiar dacă nu neapărat în cadrul unui monument istoric și nici în cel al unei zone construite protejate, arborii din București au fost în continuare „toaletați” și în Februarie 2019 (8).

Dar principiul întreținerii curente nu este singurul element pe care spatiile verzi îl împărtășesc cu clădirile protejate într-un fel sau altul. Frecvent, tipurile de valori culturale care ne determină să le prețuim pe cele din urmă se manifestă în și prin cele din dintâi, cel mai elocvent exemplu în acest sens fiind parcurile istorice. Astfel, de pildă, dacă este abordat prin prisma metodologiei de clasare, Parcului Carol i se pot atribui fără probleme calificative consistente la toate criteriile specifice monumentelor istorice: vechime, trăsături urbanistice, arhitecturale și artistice, caracterul de unicat, respectiv atribute memorial-simbolice (9).

Pe scurt, dar generalizând, din punct de vedere axiologic, un parc clasat nu diferă în nici un fel față de orice altă formă de monument istoric. Măcar și numai din acest motiv, specialiștii care au elaborat prima variantă postbelică (dar) nepolitizată a Listei Monumentelor Istorice nu au omis spațiile verzi amenajate, iar după intrarea în vigoare a legii de profil, cel puțin cele din București au fost toate clasate în calitate de ansambluri (I0). În termenii aceleiași legi, aceasta înseamnă că un astfel de parc este privit ca ,grup coerent din punct de vedere cultural, istoric, arhitectural, urbanistic or muzeistic de construcții urbane sau rurale care împreună cu terenul aferent formează $\bigcirc$ unitate delimitată topografic ce constituie o mărturie cultural istorică semnificativă din punct de vedere arhitectural, urbanistic, arheologic, istoric, artistic, etnografic, religios, social, științific sau tehnic" (II). Evident, ceea ce ridică semne de întrebare și creează dificultăți în a cuprinde în această definiție (de origine științifică, dar în traducere juridică) spațiile verzi amenajate este cuvîntul „construcții” - care, într-adevăr, în limba română, este înțeles în primul rând drept „clădire executată din zidărie, lemn, metal, beton etc.”( I 2).Dar, pe de altă parte, „construcție” înseamnă și „alcătuire, compunere” (I3) - adică rezultatul actului de a construi care, la rândul său, se definește drept acțiunea de ,a forma un întreg” (I4) - indiferent de materia primă utilizată în acest scop. Cu alte cuvinte, termenul „construcție” poate desemna și o compoziție realizată din vegetație și, prin urmare, în sensul legii citate (422 / 200 I), prin ,ansamblu” se poate înțelege și un grup format, de exemplu, atât din clădiri, cât și din plante sau practic exclusiv din plante - adică, între altele, un parc.

Acest punct de vedere, respectiv această interpretare, se bazează și pe documente internaționale precum Carta grădinilor istorice, adoptată de ICOMOS (International Council for Monuments and Sites) în anul 1982 (I5).

Primul său articol este mai mult decât elocvent - pe de o parte pentru că definește grădinile istorice drept compoziții - adică drept alcătuiri (în general) - și anume drept compoziții arhitecturale și horticole.

Pe de altă parte, același articol întâi afirmă că, dacă astfel de compoziții sunt de interes public din punct de vedere 
istoric sau artistic ele trebuie să fie considerate monumente istorice. (16) În plus, expresia „compoziție arhitecturală și horticolă" este explicată în articolul $4 \mathrm{ca}$ incluzând planul și topografia, vegetația, ca specii, proporții, scheme de culoare, spațiere și înălțimi, componentele clădite și decorative, precum și apa, indiferent de ipostază, dar oglindind întotdeauna cerul. ( I 7) Cu alte cuvinte, vegetația este privită drept un set de materiale de construcție, cu anumite trăsături, prin a căror punere în operă, pe baza unui plan conceput pentru o anume topografie, se obține, alături de apă, edificii, obiecte de artă ș.a.a. nimic altceva decât ... un ansamblu coerent cu anume calități.

Această pledoarie pentru înțelegerea grădinilor și parcurilor istorice cu valori culturale ca monumente istorice - ca oricare altele - este necesară dintr-un motiv care prezintă minimum două ramificații semnificative.

În ambele cazuri este vorba despre tentația de a considera grădinile și parcurile istorice cu valoare culturală drept altceva, adică drept un alt fel de monumente istorice, implicațiile fiind, însă, ca și motivațiile în cauză, diferite. Astfel, probabil dintr-un exces de interes (de altfel ușor de înțeles în condițiile din România în care mediul natural în general este desconsiderat), cel puțin în urmă cu trei ani, într-o scrisoare adresată grupului de lucru format pentru elaborarea unui cod al patrimoniului cultural, Asociația Peisagiștilor din România susținea faptul că peisajul este „ం categorie aparte” care trebuie „să dispună de metodologii de identificare, evaluare, clasare și interventie specifice”. În același document, aceeași organizație consideră de asemenea că peisajul reprezintă „o compoziție de spații create sau modificate de om pentru a servi drept infrastructură sau background pentru existența noastră colectivă” (I8). Evident, în aceste condiții, grădinile și parcurile - oricum frecvent create intenționat ca peisaje (în sensul uzual al termenului) și deci cuprinse în definiția menționată - ar trebui considerate, la rândul lor, un gen aparte de monument istoric.

Or, introducerea unei astfel de distincții - în cazul de față nu doar de natură juridică, ci și științifică - nu este nici în favoarea patrimoniului cultural în general și, implicit, nici în favoarea spatiilor verzi amenajate clasate.

Din punctul de vedere al patrimoniului cultural în general, adică în ceea ce privește numai acea parte din toată moștenirea care se deosebește prin valori culturale, se impune un unic set de criterii de departajare față de celelalte componente (ordinare) de patrimoniu.

În caz contrar, adică în cazul în care nu se poate face o distincție clară între patrimoniul cultural și moștenirea lipsită de valori culturale, cel dintâi pierde din semnificație și deci dreptul la protecție. În plus, aplicarea unui set unic de criterii de evaluare culturală este utilă și în stabilirea ierarhiei prin care putem raporta patrimoniul cultural national la cel international, adică la Lista Patrimoniului Mondial, cunoscută drept Lista UNESCO. Prin urmare, a introduce criterii și instrumente diferențiate de evaluare culturală echivalează cu relativizarea însăși a noțiunii de patrimoniu cultural - ceea ce, în ultimă instanță, nu poate fi benefic nici spatiilor verzi amenajate cu valori culturale.

Pe de altă parte,evident, monumentele istorice „clasice”, adică cele care sunt, în fapt, clădiri, ansambluri de edificii, porțiuni de țesut de așezare sau chiar sate și orașe întregi, se deosebesc de grădinile și parcurile clasate din punctul de vedere al „materialelor de constructie”. Acestea din urmă sunt alcătuite în parte din vegetatie, iar vegetatia nu este doar trecătoare, ci și unul din cele mai puternice simboluri ale regenerării - motiv pentru care apare și există inevitabil tendința de a o neglija.

Numai că, în cazul spațiilor verzi amenajate declarate monumente istorice, neglijarea componentei „verzi” poate determina și pierderea - chiar dacă numai 
temporară - a unor valori culturale. Această certitudine reprezintă un al doilea motiv pentru care nu trebuie ratată nici o ocazie de a sublinia faptul că grădinile și parcurile clasate sunt monumente istorice ca oricare altele și că necesită deci aceeași atenție și același tratament, preferabil preventiv decât curativ.

Deși este de prisos, fiind un fapt evident, clasarea unui spațiu verde amenajat, adică atribuirea statutului de monument istoric și deci asigurarea protecției legale aferente acestuia, nu înseamnă renunțarea la instrumentele similare puse însă direct în slujba mediului natural.(19) În fapt, în calitate de rod al unui cumul de elemente diferite, (pe scurt) clădiri și vegetație, parcurile, grădinile și cele asemenea lor trebuie înțelese și abordate, nu doar științific, ci și legal, ca un cumul de valori.

Parcul Carol, monument istoric - „un ansamblu coerent cu calități”. Foto: Vlad Eftenie

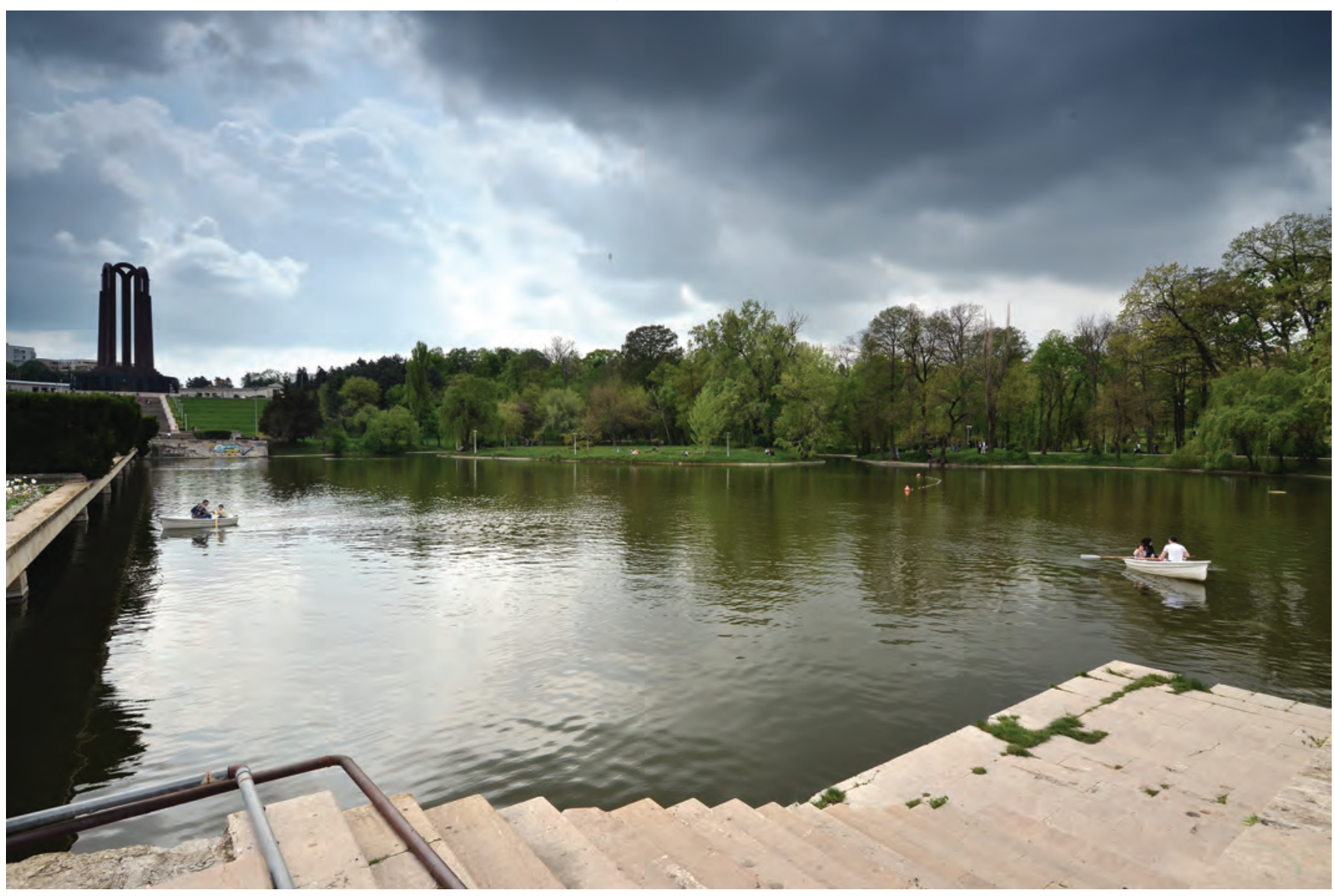


I. De exemplu, Agerpres, Arh. Tomnița Florescu, viceprimarul Capitalei: Parcul Carol va deveni, în 10 ani, un nou pol cultural al Bucureștiului,https://wwwb.agerpres.ro/administratie/2018/06/05/ar h-tomnita-florescu-viceprimarul-capitalei-parcul-carol-va-deveni-inI0-ani-un-nou-pol-cultural-al-bucurestiului- 12 | 328, sursă consultată si în data de 23.03.2019.

2. Rezoluții, http://www.cultura.ro/sites/default/files/inline-files/SUZP 13 decembrie 2018 -rezolutii - site-converted.pdf, document consultat si în data de 23.03.2019.

3. În conformitate cu documentul aflat pe pagina de internet a ministerului de resort (vezi nota 2), în luna decembrie a anului 20।8, secțiunea „Urbanism și zone construite protejate” a avizat favorabil cu condiții propunerile de modificare a limitelor care definesc trei zone construite protejate din Bucuresti și anume cele cu numerele 8I, 82 și 83, zone construite protejate care corespund parcurilor Cișmigiu, Carol I și Herăstrău.

4. În conformitate cu Lista Monumentelor Istorice în vigoare - LMI (20I5), în București, sunt clasate și deci se bucură (după caz, și) de regimul juridic de protectie specific parcurile Carol (B-II-a-A-I90I6), Herăstrău (B-II-a-A-I 8802), loanid (B-II-a-A-I8300), Kiseleff (B-II-aB- I 8982), Plumbuita (B-II-a-B- I8444) și grădinile Botanică (B-II-a-BI8508), Cișmigiu (B-II-a-A-I 9655) și Icoanei (B-II-a-B-I830I). La aceste spații verzi publice se adaugă Parcul dendrologic din cadrul Academiei de Științe Agricole și Silvice „Gheorghe lonescu-Sisești” (B-II-m-A-2 1045.06) care are, evident, alt regim de utilizare. 5. Ciobotă, Alex. et alii (2017), Ghid de bună practică pentru administrarea spatiilor verzi, Timișoara, 2017, p. 21.

6. Rundă de discuții la care a asistat și autoarea textului de față care, pe atunci, îndeplinea funcția de președinte al Comisiei Naționale a Monumentelor Istorice, for direct interesat în prezervarea Monumentelor istorice și a zonelor construite protejate, în principal prin întreținere curentă corectă.

7. Informația respectivă a fost actualizată în primăvara anului 2018 pentru comunicarea omonimă din cadrul conferinței intitulate „Patrimoniul artistic, arhitectural și natural din Parcul Carol”, manifestare desfășurată sub egida Universității de Arhitectură și Urbanism „lon Mincu”, a Asociației Profesionale a Urbaniștilor din România, precum și a Academiei de Științe Tehnice din România. 8. Știrile ProTV, Toaletarea arborilor făcută de muncitori după cum îi taie capul. „Facem noi cum știm”, https://stirileprotv.ro/stiri/actualitate/toaletarea-arborilor-facuta-de-muncitori-dupa-cum-ii-taie-capulfacem-noi-cum-stim.html, sursă consultată și în data de 23.03.2019.
9. Drăgan, V. (2006).

10. Vezi nota 4. Singura excepție de la principiul clasării în calitate de ansamblu o constituie parcul dendrologic din cadrul Academiei de Științe Agricole și Silvice „Gheorghe lonescu-Sisești”, în condițiile în care aceasta din urmă este clasată ca ansamblu, iar toate componentele sale sunt clasate ca imobile.

I I. 422 / 200 I, art. 3b.

12. DEX, https://dexonline.ro/definitie/constructie, sursă consultată și la data de 23.03.2019.

13. Idem.

14. DEX, https://dexonline.ro/definitie/a construi, sursă consultată și la data de 23.03.2019.

15. ICOMOS, https://www.icomos.org/images/DOCUMENTS/Charters/gardens_e.pdf., document consultat și în data de 23.03.2019.

16. „A historic garden is an architectural and horticultural composition of interest to the public from the historical or artistic point of view. As such, it is to be considered as a monument" ICOMOS, https://www.icomos.org/images/DOCUMENTS/Charters/gardens_e.pdf., articolul I, document consultat și în data de 23.03.2019.

17.,,The architectural composition of the historic garden includes: Its plan and topography. Its vegetation, including its species proportions, colour schemes, spacing and respective heights. Its structural and decorative features. Its water, running or still, reflecting the sky." - ICOMOS,

https://www.icomos.org/images/DOCUMENTS/Charters/gardens_e .pdf., articolul 4, document consultat și în data de 23.03.2019.

18. ASOP (2016), p. 3 (toate citatele).

19. În acest context, este irelevant faptul că, în prezent, în România, statutul juridic de monument istoric nu asigură - în practică - toată protecția enunțată prin lege, după cum, din păcate, nici mediul natural nu este apărat suficient - în practică.

\section{Referințe}

ASOP (2016). Punctul de vedere al Asociației Peisagiștilor din România cu privire la elaborarea Codului Patrimoniului Cultural Național, f.l., document înregistrat sub numărul B.00I.0I / 05.02.2016.

Ciobotă, Alex. et alii (2017). Ciobotă, Alexandru; Rusu, Raluca Ramona; Culescu Diana Lavinia; Boancă, Păunița luliana; Condoroș, 
Andrei; Borș-Oprișa, Sonia; Bedelean, Rebecca loana; Răducu-Lefter, Andreea; Koos, Teodora Aureliana; Sîrca, Maria Teodora; Mihalciuc,

luliana; Weber, Cordula. Ghid de bună practică pentru administrarea spațiilor verzi, Timișoara, 2017.

Drăgan, V. (2006). Studiu istoric pentru Parcul Carol l, imobil situat în Piața Libertății, sectorul 4, delimitat de: Piața Libertății, str. G-ral Candiano Popescu, Calea Șerban Vodă, str. Cuțitul de Argint și str. dr. Constantin Istrati. Analiza valorilor culturale ale imobilului și ale zonei învecinate. Reguli generale de interventie pentru conservarea valorilor culturale și integrarea în zonă, f.l., 2006, manuscris pus la dispozitie de autor.

LMI (20I5). Lista monumentelor istorice, anexă la ordinul

2.828/20 I05, pentru modificarea anexei $\mathrm{nr}$. I la Ordinul ministrului culturii și cultelor nr. 2.3।4/2004 privind aprobarea Listei monumentelor istorice, actualizată, și a Listei monumentelor istorice dispărute, cu modificările ulterioare din 24.12.20 I5; Monitorul Oficial al României, Partea I, Nr. II3 bis, I5.02.20I6.

PUZ ZCP (2000). Plan urbanistic zonal - zone construite protejate București, 2000.

\section{Webografie}

Agerpres https://wwwb.agerpres.ro/administratie/2018/06/05/arhtomnita-florescu-viceprimarul-capitalei-parcul-carol-va-deveni-in- 10 ani-un-nou-pol-cultural-al-bucurestiului-- 121328 , sursă consultată și în data de 23.03.2019.

DEX https://dexonline.ro/definitie/, sursă consultată și la data de 23.03.2019.

ICOMOS, https://www.icomos.org/images/DOCUMENTS/Charters/gardens_e.pdf., document consultat și în data de 23.03.20I9. Rezolutii http://www.cultura.ro/sites/default/files/inline-files/SUZP I 3 decembrie 2018 -rezolutii - site-converted.pdf, document consultat și în data de 23.03.2019.

Știrile ProTV, Toaletarea arborilor făcută de muncitori după cum îi taie capul. „Facem noi cum știm”, https://stirileprotv.ro/stiri/actualitate/toaletarea-arborilor-facuta-de-muncitori-dupa-cum-ii-taiecapul-facem-noi-cum-stim.html, sursă consultată și în data de 23.03.2019.

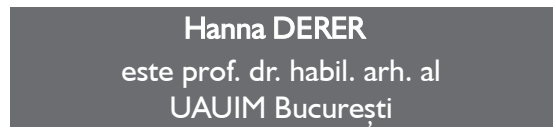

